\title{
Performance and kinetics of ANAMMOX granular sludge with pH shock in a sequencing batch reactor
}

\author{
Jin Li $\mathbb{B} \cdot$ Weiqiang Zhu $\cdot$ Huiyu Dong $\cdot$ Dan Wang
}

Received: 28 December 2016/Accepted: 27 April 2017/Published online: 29 April 2017

(C) Springer Science+Business Media Dordrecht 2017

\begin{abstract}
As an efficient and cost-effective nitrogen removal process, anaerobic ammonium oxidation (ANAMMOX) could be well operated at suitable $\mathrm{pH}$ condition. However, $\mathrm{pH}$ shock occurred in different kinds of wastewater and affected ANANNOX process greatly. The present research aimed at studying the performance and kinetics of ANAMMOX granular sludge with $\mathrm{pH}$ shock. When influent $\mathrm{pH}$ was below 7.5, effluent $\mathrm{NH}_{4}^{+}-\mathrm{N}$ and $\mathrm{NO}_{2}^{-}-\mathrm{N}$ increased with decreasing $\mathrm{pH}$. At $\mathrm{Ph}$ 6.0, effluent $\mathrm{NO}_{2}^{-}-\mathrm{N}$ approached $100 \mathrm{mg} / \mathrm{L}$, and the ratios of $\Delta \mathrm{NO}_{2}^{-}-\mathrm{N}: \Delta \mathrm{NH}_{4}^{+}-$ $\mathrm{N}$ and $\Delta \mathrm{NO}_{3}^{-}-\mathrm{N}: \Delta \mathrm{NH}_{4}^{+}-\mathrm{N}$ approached 2.2 and 1.3, respectively. Both greatly deviated from
\end{abstract}

Electronic supplementary material The online version of this article (doi:10.1007/s10532-017-9793-x) contains supplementary material, which is available to authorized users.

J. Li $(\bowtie) \cdot$ W. Zhu

School of Environmental Science and Engineering, Qingdao University, Qingdao 266071, China

e-mail: ljin0532@126.com

H. Dong

Key Laboratory of Drinking Water Science and Technology, Research Center for Eco-environmental Sciences, University of Chinese Academy of Sciences,

Chinese Academy of Sciences, Beijing 100085, China

D. Wang

National Marine Environmental Forecasting Center, State

Oceanic Administration, Beijing 100081, China theoretical values. When influent $\mathrm{pH}$ was above 7.5, effluent $\mathrm{NH}_{4}^{+}-\mathrm{N}$ and $\mathrm{NO}_{2}^{-}-\mathrm{N}$ increased with increasing $\mathrm{pH}$. At $\mathrm{pH}$ 9.0, ammonium removal rate (ARR) and nitrite removal rate (NRR) decreased to $0.011 \pm 0.004$ and $0.035 \pm 0.004 \mathrm{~kg} /\left(\mathrm{m}^{3} \cdot \mathrm{d}\right)$, respectively. Besides, $\Delta \mathrm{NO}_{2}^{-}-\mathrm{N}: \Delta \mathrm{NH}_{4}^{+}-\mathrm{N}$ deviated from theoretical value. Longer recovery time from $\mathrm{pH} 9.0$ than from $\mathrm{pH} 6.0$ indicated that alkaline surroundings inhibited anaerobic ammonium oxidizing bacteria (AAOB) greater. The sludge settling velocity was $2.15 \mathrm{~cm} / \mathrm{s}$ at $\mathrm{pH}$ 7.5. However, it decreased to $2.02 \mathrm{~cm} / \mathrm{s}$ when $\mathrm{pH}$ was 9.0. Acidic $\mathrm{pH}$ had little effect on sludge size, but disintegration of ANAMMOX granule was achieved with $\mathrm{pH}$ of 9.0. The Bell-shaped (A) model and the Ratkowsky model were more applicable to simulate the effect resulting from $\mathrm{pH}$ shock on ANAMMOX activity $\left(\mathrm{R}^{2}>0.95\right)$, and both could describe ANAMMOX activity well with $\mathrm{pH}$ shock. They indicated that $\mathrm{q}_{\max }$ was $0.37 \mathrm{~kg}$ $\Delta \mathrm{NH}_{4}^{+}-\mathrm{N} /(\mathrm{kgMLSS} \cdot \mathrm{d})$ at the optimum $\mathrm{pH}$ value (7.47) in present study. The minimum $\mathrm{pH}$ during which ANAMMOX occurred was 5.68 while the maximum $\mathrm{pH}$ for ANAMMOX reaction was 9.26. Based on nitrogen removal performance with different $\mathrm{pH}$, strongly acidic $(\mathrm{pH} \leq 6.5)$ or alkaline $(\mathrm{pH} \geq 8.5)$ inhibited ANAMMOX process. Besides, ANAMMOX appeared to be more susceptible to alkaline wastewater. Compared to extremely acidic condition (low $\mathrm{pH}$ ), extremely alkaline condition (high $\mathrm{pH}$ ) affected ANAMMOX granules much more. 
Keywords ANAMMOX $\cdot \mathrm{pH}$ shock $\cdot$ Nitrogen removal $\cdot$ Particle size distribution $(\mathrm{PSD}) \cdot$ Kinetics

\section{Introduction}

As a feasible and promising biological wastewater treatment technology, anaerobic ammonium oxidation (ANAMMOX) has attracted more and more attention. During the process, ammonium was oxidized to nitrate with nitrite as electron acceptor according to Eq. 1 (Strous et al. 1998). Many advantages of ANAMMOX made it popular in wastewater treatment (Okamoto et al. 2012; Qiao et al. 2009). However, ANAMMOX process was greatly affected by many factors such as pH (Daverey et al. 2015), organic matter (Li et al. 2015) and free ammonia (Aktan et al. 2012). With regard to $\mathrm{pH}$, Strous et al. (1999) reported that physiological $\mathrm{pH}$ range of ANAMMOX bacteria was 6.7-8.3 while Egli et al. (2001) indicated the value was 6.5-9. Although the activity of ANAMMOX bacteria could still be found with extreme alkaline or acidic surroundings (Ahn et al. 2004; Yin et al. 2016), ANAMMOX process was greatly affected by $\mathrm{pH}$ shock.

$$
\begin{aligned}
\mathrm{NH}_{4}^{+} & +1.32 \mathrm{NO}_{2}^{-}+0.066 \mathrm{HCO}_{3}^{-}+0.13 \mathrm{H}^{+} \\
\rightarrow & 1.02 \mathrm{~N}_{2}+0.26 \mathrm{NO}_{3}^{-}+0.066 \mathrm{CH}_{2} 0_{0.5} \mathrm{~N}_{0.15} \\
& +2.03 \mathrm{H}_{2} \mathrm{O}
\end{aligned}
$$

Numerous studies were focused on the effect of $\mathrm{pH}$ on wastewater treatment_ENREF_35_ENREF_14_ ENREF_37. On the one hand, both the growth and activity of microbes were directly affected by $\mathrm{pH}$ (Fux et al. 2004; Strous et al. 1997; Tang et al. 2009; Yin et al. 2016)._ENREF_45_ENREF_37_ENREF_14 On the other hand, $\mathrm{pH}$ affected free ammonia (FA) and free nitrous acid (FNA) contents, which influenced biochemical reaction process indirectly (Fernandez et al. 2012; Puyol et al. 2014a, b; Tang et al. 2009; Waki et al. 2007)._ENREF_37_ENREF_42_ENREF_12_ENREF_37_ENREF_42 With regard to direct effect resulting from $\mathrm{pH}$, Strous et al. (1997) reported that specific ANAMMOX activity (SAA) at $\mathrm{pH} 9$ was only $20 \%$ of that at pH 8 . Fux et al. (2004) found that ANAMMOX activity was completely inhibited at $\mathrm{pH}$ 9.3 in a fixed-bed reactor. Besides, Yin et al. (2016) showed that very low nitrogen removal efficiencies
$(<7 \%)$ were achieved with extreme initial $\mathrm{pH}$ values (i.e. 6.0 or 10.5). However, the results varied with different reactor configurations or wastewater characteristics.

As pH-dependent parameters, FA and FNA could indirectly affect ANAMMOX process. With high $\mathrm{pH}$, FA was regarded as an inhibitor. Tang et al. (2009) observed the loss of ANAMMOX stability due to $70 \mathrm{mg} / \mathrm{L}$ FA resulting from increasing $\mathrm{pH}$. Waki et al. (2007) suggested that the deterioration of ANAMMOX system occurred at 13-90 mg/L FA. Fernandez et al. (2012) indicated that a 50\% decrease of SAA was obtained at $38 \mathrm{mg} / \mathrm{L} \mathrm{FA}$ while $80 \%$ decrease was got at $100 \mathrm{mg} / \mathrm{L}$ FA. FNA was also thought to be an important contributor to ANAMMOX inhibition when pH was lower than 7.1 (Puyol et al. 2014a). Jung et al. (2007) reported that $0.8-1.2 \mu \mathrm{g} / \mathrm{L}$ FNA significantly inhibited the ANAMMOX process. Fernandez et al. (2012) found that $6.6 \mu \mathrm{g} / \mathrm{L}$ FNA had no significant inhibition on anaerobic ammonium oxidizing bacteria (AAOB) in batch tests, and a decrease over $50 \%$ was obtained when FNA was $11 \mu \mathrm{g} / \mathrm{L}$.

There were numerous high-strength ammonium wastewater with various $\mathrm{pH}$ values (Chung and Bae 2002; Chung et al. 2007). As a result, it is necessary to study nitrogen removal performance of ANAMMOX with $\mathrm{pH}$ shocks. The present work aimed at studying $\mathrm{pH}$ shock on process stability and recovery process after inhibition. Besides, sludge property and kinetics were analyzed.

\section{Materials and methods}

Experimental set-up and operational strategy

Two anaerobic sequencing batch reactors (SBRs) were operated in parallel in this work and each reactor was $1.5 \mathrm{~L}$. Two reactors were covered completely with aluminum caps to avoid the growth of photosynthetic microorganisms. $\mathrm{N}_{2}(99.99 \%)$ was purged into the influent in order to maintain anaerobic conditions. Besides, each reactor was bubbled with $\mathrm{N}_{2}$ gas to remove dissolved oxygen before sludge was inoculated into it. Hydraulic retention time (HRT) was $6 \mathrm{~h}$. During the experiment, SBRs were stirred at $100 \mathrm{rpm}$. In order to study the effect resulting from FNA and FA on ANAMMOX process, $\mathrm{NH}_{4}^{+}-\mathrm{N}$ decreased to $40 \mathrm{mg}$ / 
$\mathrm{L}$ at $\mathrm{pH} 6$ and $\mathrm{NO}_{2}^{-}-\mathrm{N}$ decreased to $53 \mathrm{mg} / \mathrm{L}$ at $\mathrm{pH} 9.0$ (Anthonisen et al. 1976). $\mathrm{NH}_{4}^{+}-\mathrm{N} / \mathrm{NO}_{2}^{-}-\mathrm{N}$ was kept at 1.32 (according to Strous et al. 1998) except P5 and P11. The detailed operational strategy was presented in Table 1.

Inoculated sludge and synthetic wastewater

ANAMMOX granular sludge was inoculated from two lab-scale reactors (with an effective volume of 7 L). Both reactors were operated steadily over one year at $35 \pm 1{ }^{\circ} \mathrm{C}$ with influent $\mathrm{pH}$ of 7.5. The inoculating sludge was mixed and added into two SBRs. The sludge concentration was $1.55 \pm 0.05 \mathrm{~g} / \mathrm{L}$ in both SBRs and the sludge retention time (SRT) was about 30 days. The granular sludge was brightly red with good settling property (shown in Fig. S1). Synthetic wastewater was used in this study $(\mathrm{g} / \mathrm{L}): \mathrm{KH}_{2} \mathrm{PO}_{4}$ 0.028; $\mathrm{CaCl}_{2} 0.14 ; \mathrm{KHCO}_{3} 2.0 ; \mathrm{MgSO}_{4} \cdot 7 \mathrm{H}_{2} \mathrm{O} 0.2$; $\mathrm{NH}_{4} \mathrm{Cl}$ 0.336; $\mathrm{NaNO}_{2}$ 0.573. Trace element solutions I and II (1.2 ml per litre medium) were also added as previous reported (Van de Graaf et al. 1996).

Specific ANAMMOX activity (SAA) batch assays

To test the effects of $\mathrm{pH}$ shocks on ANAMMOX activity, batch assays were carried out under different $\mathrm{pH}$ values at $35^{\circ} \mathrm{C}$. Completely closed vials with a total volume of $100 \mathrm{~mL}$ of liquid volume were used to perform ANAMMOX batch assays. The $\mathrm{NH}_{4}^{+}-\mathrm{N} /$ $\mathrm{NO}_{2}^{-}-\mathrm{N}$ concentrations were 80 and $105 \mathrm{mg} / \mathrm{L}$, respectively. At the initial of test, sludge concentration was $1.55 \mathrm{~g} / \mathrm{L} . \mathrm{N}_{2}$ was purged into reactors to remove $\mathrm{O}_{2}$. The determination was performed at regular intervals $(0.5 \mathrm{~h})$ and SAA was calculated according to the report from Qiao et al. (2014).

Analytical methods

The supernatants were analyzed for $\mathrm{NH}_{4}^{+}-\mathrm{N}, \mathrm{NO}_{2}^{-}-\mathrm{N}$ and $\mathrm{NO}_{3}^{-}-\mathrm{N}$ concentrations according to standard methods (APHA 1998). Temperature and $\mathrm{pH}$ were measured by WTW 340i/SET pH/Oxi portable multiparameter meter. Microscopic images were taken with light microscope (Olympus, CX31) and photos were taken with digital camera (Canon, IXUS 500 HS). Sludge concentration was measured after filtering the washed samples through $0.45 \mu \mathrm{m}$ membrane filter and drying at $105{ }^{\circ} \mathrm{C}$ to constant weight. Each analytical result reported in present research was performed in triplicate and the mean value was reported. The size of granular sludge was performed according to method described by Tang et al. (2011). The measure of settling velocity was based on the methods of Mu et al. (2008). The FA and FNA concentrations were acquired according to previous report from Anthonisen et al. (1976).

Kinetic analysis

The kinetic analysis at different influent $\mathrm{pH}$ (6.0-9.0) was carried out in batch tests. The influent $\mathrm{pH}$ in different tests were adjusted by adding $\mathrm{HCl}(1 \mathrm{~mol} / \mathrm{L})$ and $\mathrm{NaOH}(2 \mathrm{~mol} / \mathrm{L})$.
Table 1 Operational strategy

\begin{tabular}{llllll}
\hline Reactor & Phase & Cycle & $\mathrm{NH}_{4}^{+}-\mathrm{N}^{\mathrm{a}}(\mathrm{mg} / \mathrm{L})$ & $\mathrm{NO}_{2}^{-}-\mathrm{N}^{\mathrm{a}}(\mathrm{mg} / \mathrm{L})$ & $\mathrm{pH}^{\mathrm{b}}$ \\
\hline SBR1 & P1 & $0-15$ & 80 & 106 & 7.5 \\
& $\mathrm{P} 2$ & $15-25$ & 80 & 106 & 7.0 \\
& $\mathrm{P} 3$ & $25-35$ & 80 & 106 & 6.5 \\
& P4 & $35-45$ & 80 & 106 & 6.0 \\
& P5 & $45-55$ & 80 & 53 & 6.0 \\
& P6 & $55-75$ & 80 & 106 & 7.5 \\
& P7 & $0-15$ & 80 & 106 & 7.5 \\
& P8 & $15-25$ & 80 & 106 & 8.0 \\
& P9 & $25-35$ & 80 & 106 & 8.5 \\
& P10 & $35-45$ & 80 & 106 & 9.0 \\
& P11 & $45-55$ & 40 & 106 & 9.0 \\
& P12 & $55-116$ & 80 & 106 & 7.5 \\
\hline
\end{tabular}


The bell-shaped (A) model

This model was applied to describe the inhibition on biological nitrification resulting from $\mathrm{pH}$ (Park et al. 2007). In present study, it was applied to analyze $\mathrm{pH}$ on ANAMMOX activity. The model was constructed by a cosine bell-shape (A) function based on an assumption that the specific substrate removal rate was zero when $\mathrm{pH}$ reached an upper limit $\left(\mathrm{pH}=\mathrm{pH}_{\text {opt }}+\omega\right)$ or a lower limit $\left(\mathrm{pH}=\mathrm{pH}_{\mathrm{opt}}-\omega\right)$.

$\mathrm{q}=\frac{\mathrm{q}_{\max }}{2} \times\left\{1+\cos \left[\frac{\pi}{\omega} \times\left(\mathrm{pH}-\mathrm{pH}_{\mathrm{opt}}\right)\right]\right\}$

where $\mathrm{q}$ and $\mathrm{q}_{\max }$ were the specific substrate $\left(\mathrm{NH}_{4}^{+}-\mathrm{N}\right.$ in this study) removal rate at certain $\mathrm{pH}$ and the optimum $\mathrm{pH}_{\text {opt }}$, respectively; The ' $\omega$ ' was defined as $\mathrm{pH}$ range in which q was larger than half of $\mathrm{q}_{\max }$; ' $2 \omega$ ' was $\mathrm{pH}$ range in which ANAMMOX could take place.

\section{The Michaelis model}

This model was applied to predict the effect resulting from $\mathrm{pH}$ shock on enzymatic reactions (Segel 1975). Besides, Yin et al. (2016) used this model to study the effect of $\mathrm{pH}$ shock on ANAMMOX reaction. The equation was presented in Eq. 3.

$\mathrm{q}=\frac{\mathrm{q}_{\max }}{1+10^{\left(\mathrm{pK}_{\mathrm{s} 1}-\mathrm{pH}\right)}+10^{\left(\mathrm{pH}^{-} \mathrm{pK}_{\mathrm{s} 2}\right)}}$

where $\mathrm{pK}_{\mathrm{s} 1}$ was logarithm of the lowest $\mathrm{pH}$ at which $\mathrm{q}$ was equal to $1 / 2 \mathrm{q}_{\max } ; \mathrm{pK}_{\mathrm{s} 2}$ was logarithm of the highest $\mathrm{pH}$ at which $\mathrm{q}$ was equal to $1 / 2 \mathrm{q}_{\max }$.

The Ratkowsky model

The Ratkowsky model (Eq. 4) was a good choice to demonstrate the effect of $\mathrm{pH}$ on hydrogen production (Wang and Wan 2009). But it was the first time applied to analyze the effect of $\mathrm{pH}$ shock on ANAMMOX activity.

$$
\begin{aligned}
\mathrm{q}= & {\left[\mathrm{A} \times\left(\mathrm{pH}-\mathrm{pH}_{\min }\right)\right]^{2} } \\
& \times\left\{1-\exp \left[\mathrm{B} \times\left(\mathrm{pH}-\mathrm{pH}_{\max }\right)\right]\right\}^{2}
\end{aligned}
$$

where $\mathrm{A}$ and $\mathrm{B}$ were constants; $\mathrm{pH}_{\min }$ and $\mathrm{pH}_{\max }$ were upper and lower limits of ANAMMOX reaction.
The Haldane model

Usually, the Haldane (Eq. 5) model was widely used to demonstrate substrate inhibition on ANAMMOX process. However, it could also describe the effect resulting from $\mathrm{H}^{+}$concentration on specific hydrogen production rate (Fabiano and Perego 2002; Wang and Wan 2009). In this study, the Haldane model was used to describe the effect of $\mathrm{pH}$ shock on ANAMMOX activity.

$\mathrm{q}=\frac{\mathrm{q}_{\max } \times \mathrm{S}_{\mathrm{H}}}{\mathrm{S}_{\mathrm{H}}+\mathrm{K}_{\mathrm{a}}+\mathrm{S}_{\mathrm{H}}^{2} / \mathrm{K}_{\mathrm{b}}}$

where $\mathrm{K}_{\mathrm{a}}$ and $\mathrm{K}_{\mathrm{b}}$ were two regression coefficients; $\mathrm{S}_{\mathrm{H}}$ was the concentration of $\mathrm{H}^{+}$.

The Bell-shaped (B) model

The function of this model was showed in Eq. 6 (Henze et al. 1995). Van Hulle et al. (2007) used the Bell-shaped (B) model to analyze SHARON kinetics, and they found that the data obtained in experiment showed a better fit to this model.

$\mathrm{q}=\mathrm{q}_{\max } \times \frac{\mathrm{K}_{\mathrm{pH}}}{\mathrm{K}_{\mathrm{pH}}-1+10^{\left|\mathrm{pH}_{\mathrm{opt}}-\mathrm{pH}\right|}}$

where $\mathrm{K}_{\mathrm{pH}}$ was $\mathrm{pH}$ constant; $\mathrm{pH}_{\mathrm{opt}}$ was the optimum $\mathrm{pH}$ value of biological process.

\section{Results and discussion}

Effect of $\mathrm{pH}$ shock on nitrogen removal performance

Nitrogen removal performance at $\mathrm{pH}<7.5$

The effect of $\mathrm{pH}$ shock $(<7.5)$ on ANAMMOX granular sludge was presented in Fig. 1. In general, when influent $\mathrm{pH}$ decreased, effluent $\mathrm{NH}_{4}^{+}-\mathrm{N}$ and $\mathrm{NO}_{2}^{-}-\mathrm{N}$ increased. $\mathrm{NO}_{2}^{-}-\mathrm{N}$ was accumulated in reactor. At $\mathrm{pH}$ 6.0, effluent $\mathrm{NO}_{2}^{-}-\mathrm{N}$ approached $100 \mathrm{mg} / \mathrm{L}$, which was regarded as the inhibition $\mathrm{NO}_{2}^{-}-\mathrm{N}$ concentration reported by Strous et al. (1999). With $\mathrm{pH}$ of 7.5-6.5, the stoichiometric ratios were similar to the reported value $\left(\Delta \mathrm{NH}_{4}^{+}-\mathrm{N}: \Delta \mathrm{NO}_{2}^{-}-\mathrm{N}: \Delta \mathrm{NO}_{3}^{-}-\mathrm{N}=1\right.$ : $1.32: 0.26)$ by Strous et al. (1998). When influent $\mathrm{pH}$ was 6.0 , the ratios of $\Delta \mathrm{NO}_{2}^{-}-\mathrm{N}: \Delta \mathrm{NH}_{4}^{+}-$ 
Fig. 1 Overall performance of ANAMMOX process at $\mathrm{pH} \leq 7.5$ : a concentrations of three nitrogen species in influent and effluent, $\mathbf{b}$ stoichiometric ratios, $\mathbf{c}$ loading and removal rates of $\mathrm{NH}_{4}^{+}-\mathrm{N}$ and $\mathrm{NO}_{2}^{-}-\mathrm{N}, \mathbf{d ~ p H}$, $\mathrm{FA}$ and FNA in influent and effluent
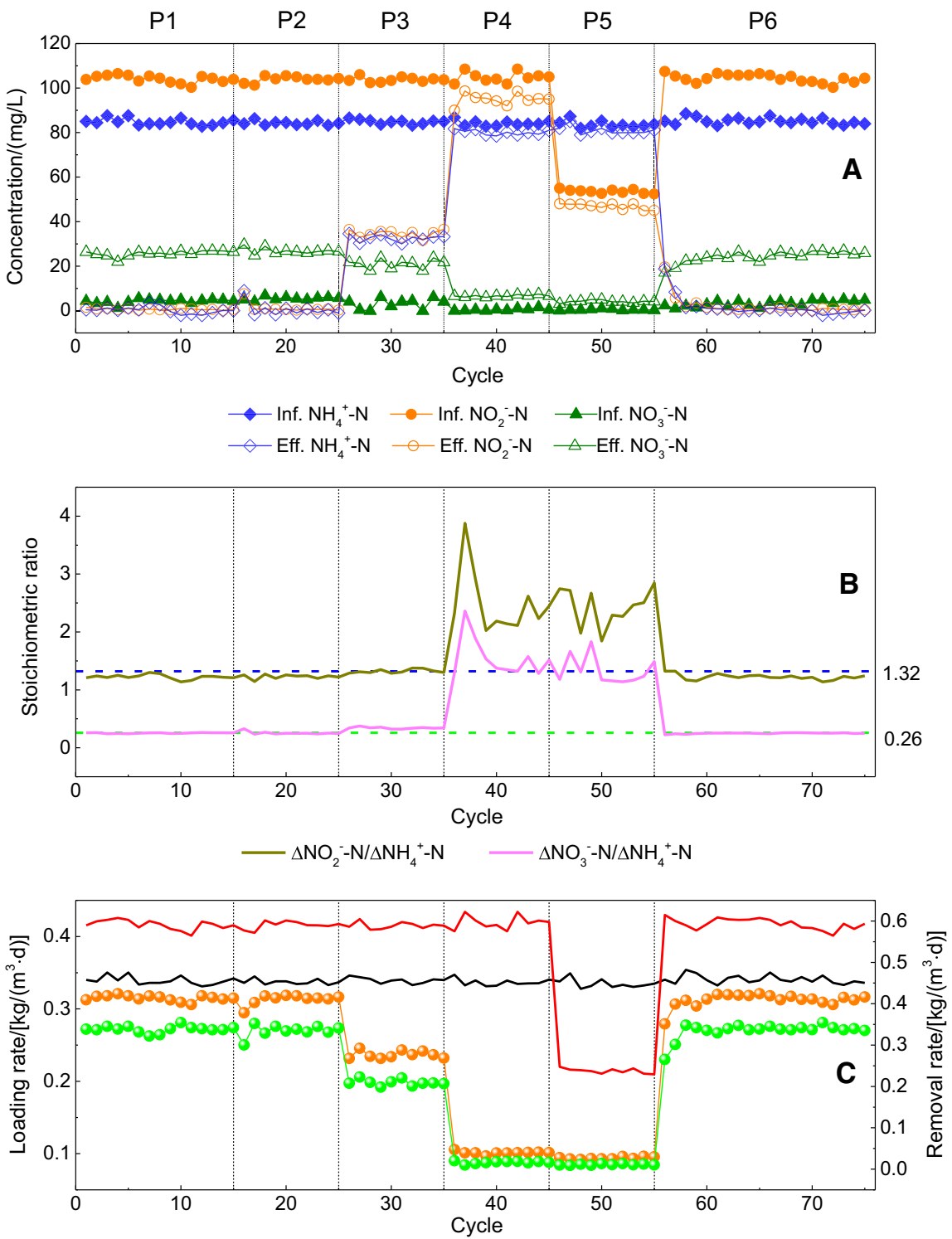

$-\mathrm{NH}_{4}^{+}-\mathrm{N}$ loading rate $-\mathrm{NO}_{2}^{-}-\mathrm{N}$ loading rate

$-\mathrm{NH}_{4}^{+}-\mathrm{N}$ removal rate $-\mathrm{NO}_{2}^{-}-\mathrm{N}$ removal rate

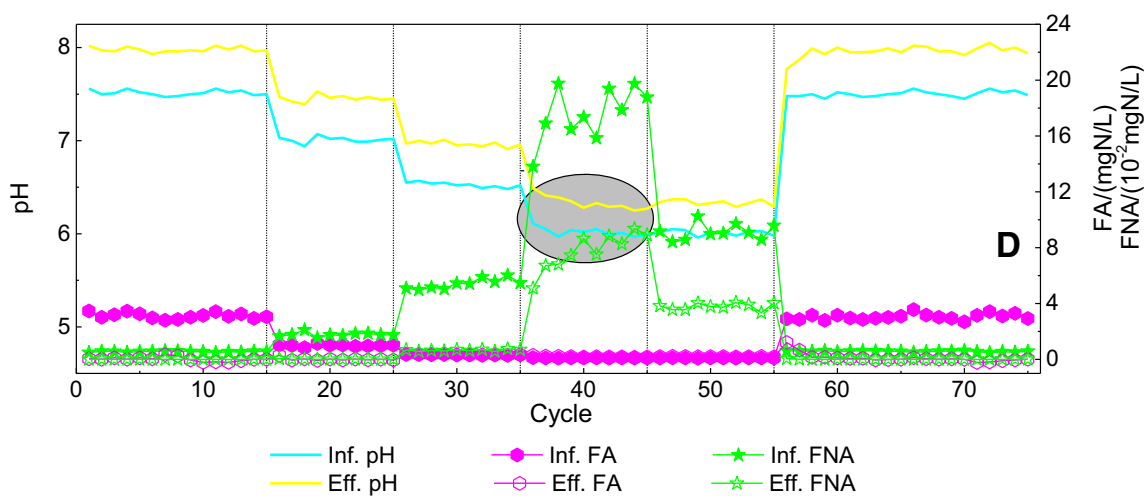


$\mathrm{N}$ and $\Delta \mathrm{NO}_{3}^{-}-\mathrm{N}: \Delta \mathrm{NH}_{4}^{+}-\mathrm{N}$ approached 2.2 and 1.3 , respectively, which deviated from theoretical values greatly.

During the period $\mathrm{P} 2-\mathrm{P} 4$, ammonium loading rate (ALR) and nitrite loading rate (NLR) were at $0.34 \pm 0.02$ and $0.41 \pm 0.02 \mathrm{~kg} /\left(\mathrm{m}^{3} \cdot \mathrm{d}\right)$, respectively. With influent $\mathrm{pH}$ decreased to 6.0, ammonium removal rate (ARR) and nitrite removal rate (NRR) decreased to $0.015 \pm 0.005$ and $0.035 \pm 0.006 \mathrm{~kg} /$ $\left(\mathrm{m}^{3} \cdot \mathrm{d}\right)$, respectively. The results implied that the ANAMMOX process was seriously impeded at $\mathrm{pH}$ 6.0. This agreed with van der Star et al. (2007) that a sharp decrease of ANAMMOX activity was observed at $\mathrm{pH}$ lower than 7.2. FA concentration was stabilized at low level (lower than $3.5 \mathrm{mg} / \mathrm{L}$ ) in this phase. However, FNA concentration was higher than the toxic threshold at $\mathrm{pH}$ 6.0. When effluent FNA concentration decreased in period $\mathrm{P} 4$, little enhancement of ARR and NRR were acquired. The decrease of FNA concentration could not improve nitrogen removal performance at strongly acidic condition.

$\mathrm{H}^{+}$was consumed when AAOB utilized $\mathrm{NO}_{2}^{-}-\mathrm{N}$ as electronic acceptor to oxidize $\mathrm{NH}_{4}^{+}-\mathrm{N}$, and it was considered as the main reason for the variation of $\mathrm{pH}$ in ANAMMOX process. The shadow zone in the Fig. 1d implied that the effluent $\mathrm{pH}$ was much higher than the influent though ANAMMOX process was almost completely inhibited. In addition, the lower alkalinity in influent resulted in decrease of buffering capacity and the degassing of $\mathrm{CO}_{2}$ from liquid into gas phase (He et al. 2015). During the recovery period P6, ANAMMOX performance could be restored after five cycles' operation.

\section{Nitrogen removal performance at $\mathrm{pH}>7.5$}

The effect of $\mathrm{pH}$ shock (>7.5) on ANAMMOX granular sludge was shown in Fig. 2. In general, when influent $\mathrm{pH}$ increased, effluent $\mathrm{NH}_{4}^{+}-\mathrm{N}$ and $\mathrm{NO}_{2}^{-}-\mathrm{N}$ increased. In addition, effluent $\mathrm{NO}_{3}^{-}-\mathrm{N}$ decreased. The stoichiometric ratios approach to theoretical value when $\mathrm{pH}$ was 7.5-8.5. However, $\Delta \mathrm{NO}_{2}^{-}-\mathrm{N}$ : $\Delta \mathrm{NH}_{4}^{+}-\mathrm{N}$ deviated from theoretical value at $\mathrm{pH} 9$. The lysis of AAOB occurred at $\mathrm{pH} 9.0$ (showed below), which released organic matter. The organic matter was consumed by HDB to remove $\mathrm{NO}_{2}^{-}-\mathrm{N}$ and $\mathrm{NO}_{3}^{-}-\mathrm{N}$. During the period P8-P10, ALR and NLR maintained at $0.34 \pm 0.02$ and $0.41 \pm 0.02 \mathrm{~kg}$ / $\left(\mathrm{m}^{3} \mathrm{~d}\right)$, respectively. When influent $\mathrm{pH}$ was 9.0, ARR and NRR decreased to $0.011 \pm 0.004$ and $0.035 \pm 0.004 \mathrm{~kg} /\left(\mathrm{m}^{3} \mathrm{~d}\right)$, respectively. This indicated that nitrogen removal performance was poor at extremely alkaline condition. This also agreed Jaroszynski et al. (2011) that high pH caused instability of ANAMMOX process.

The FNA concentration was stabilized at low level (lower than $0.0065 \mathrm{mg} / \mathrm{L}$ ), which was lower than inhibitory threshold. However, FA concentration sharply increased with growing $\mathrm{pH}$. At P10, effluent FA concentration was higher than $30 \mathrm{mg} / \mathrm{L}$, which approached the threshold of $35-40 \mathrm{mg} / \mathrm{L}$. When influent FA concentration decreased to half of that in P10, both ARR and NRR increased little. The decrease of FA could not improve nitrogen removal performance under strong alkaline condition. Puyol et al. (2014a) confirmed that high $\mathrm{pH}$ was a much more important inhibition factor than FA, which explained the result in present study.

In addition, the shadow zone in Fig. $2 \mathrm{~d}$ indicated the effluent $\mathrm{pH}$ value was higher than that in influent. In alkaline surroundings, FA generation was promoted. Besides, ANAMMOX process was nearly completely inhibited at $\mathrm{pH}$ 9.0. As a result, the consumption of $\mathrm{OH}^{-}$was higher than the production of it, which led to the decrease of $\mathrm{pH}$ value. In addition, the duration time of the recovery phase after strongly alkaline $\mathrm{pH}$ shock was much longer than acidic pH shock. 50 cycles' operation was needed to reactivate ANAMMOX process. Longer recovery time from $\mathrm{pH} 9.0$ than from $\mathrm{pH} 6.0$ indicated that alkaline surroundings inhibited AAOB greater.

\section{Mechanism of $\mathrm{pH}$ shock on ANAMMOX}

Based on the nitrogen removal performance above, both strong acidic $(\mathrm{pH} \leq 6.5)$ and alkaline conditions ( $\mathrm{pH} \geq 8.5$ ) inhibited ANAMMOX process. Besides, ANAMMOX appeared to be more susceptible to alkaline wastewater. The mechanism of $\mathrm{pH}$ shock on ANAMMOX reaction was as follows: first, extreme pHs destroyed the proton motive force. They could inhibit the associated energy generation and transform metabolic processes, including energy generation by adenosine triphosphatases (ATP) and active transport of proteins (Fig. 3) (Carvajal-Arroyo et al. 2014; Lu et al. 2013). Moreover, the denaturation of original bond cleavage, the permeability of cell membrane and 
Fig. 2 Overall performance of ANAMMOX process at $\mathrm{pH} \geq 7.5$ : a concentrations of three nitrogen species in influent and effluent, b stoichiometric ratios, c loading and removal rates of $\mathrm{NH}_{4}^{+}-\mathrm{N}$ and $\mathrm{NO}_{2}^{-}-\mathrm{N}$, d $\mathrm{pH}, \mathrm{FA}$ and FNA in influent and effluent
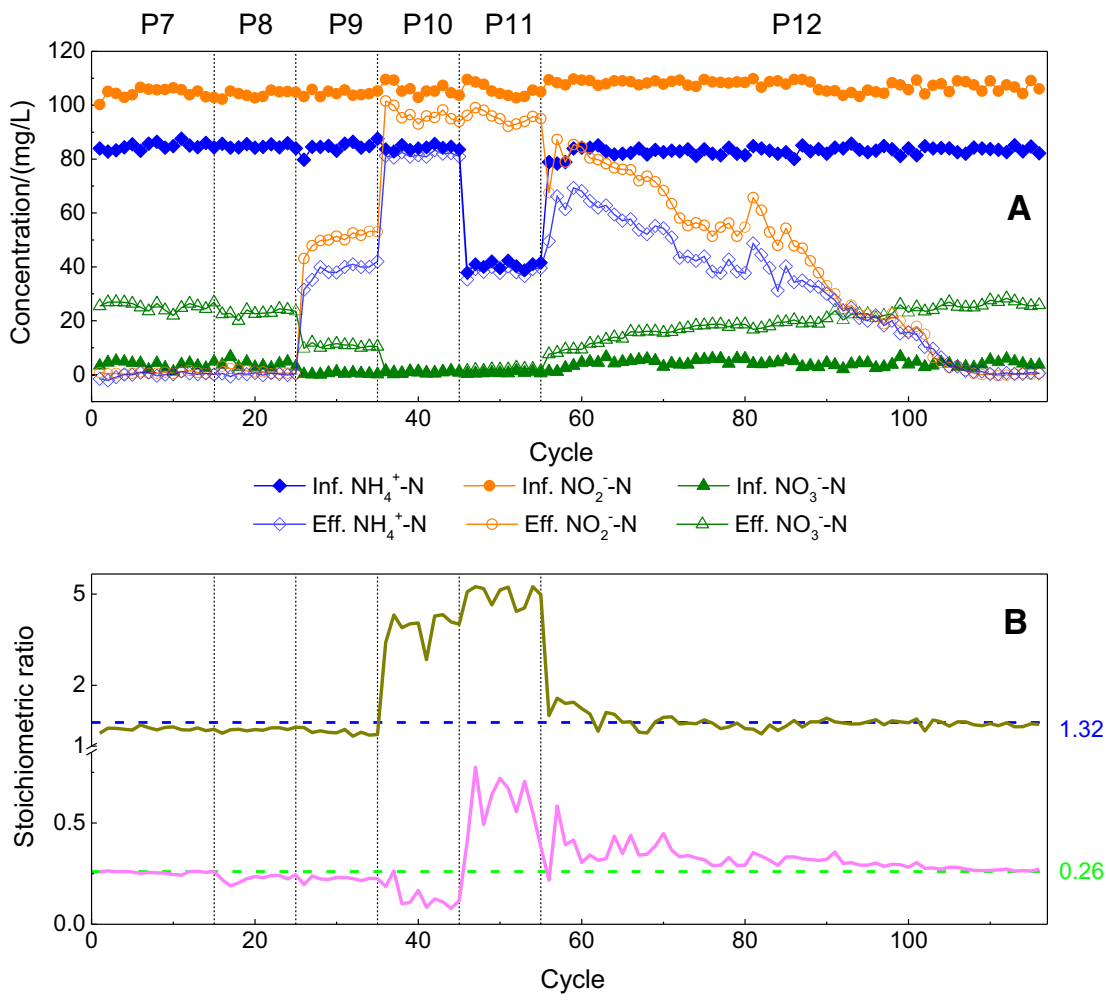

$-\Delta \mathrm{NO}_{2}{ }^{-}-\mathrm{N} / \Delta \mathrm{NH}_{4}{ }^{+}-\mathrm{N}=\Delta \mathrm{NO}_{3}{ }^{-}-\mathrm{N} / \Delta \mathrm{NH}_{4}{ }^{+}-\mathrm{N}$

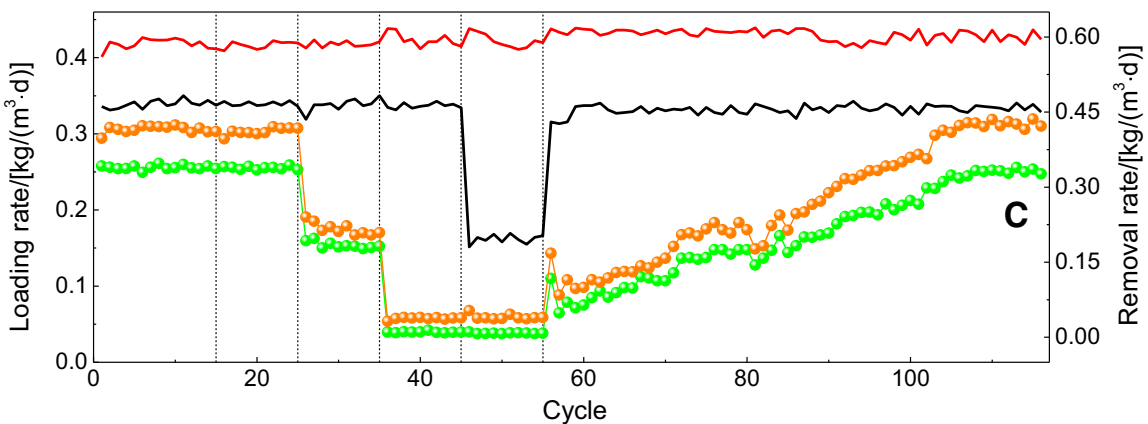

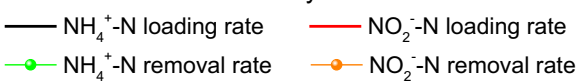

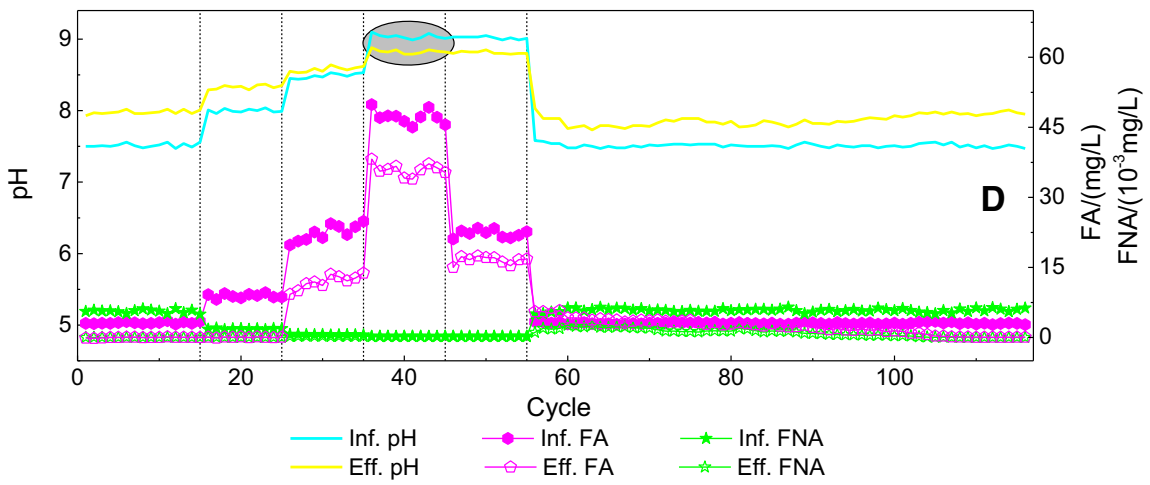


Fig. 3 Reaction mechanism occurred in AAOB with acidic and alkaline condition. (1) diffusion of FA and FNA; (2) carrier protein; (3) $\mathrm{NH}_{4}^{+}$ and $\mathrm{NO}_{2}^{-}$not diffuse into cell membrane; (4) passive transport; (5) ANAMMOX process and cell synthesis; (6) transformation between $\mathrm{NH}_{3}$ and $\mathrm{NH}_{4}^{+} ;(7)$ transformation between $\mathrm{HNO}_{2}$ and $\mathrm{NO}_{2}^{-}$

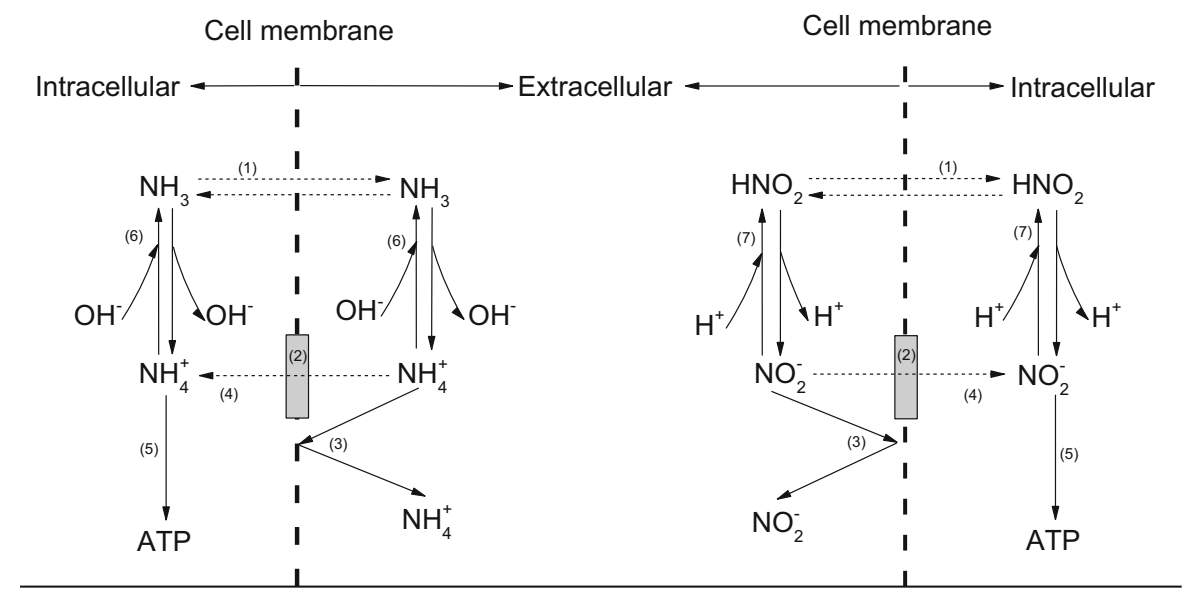

destruction of other biological structures occurred in reactor, which led to the inactivation of enzymes (Yin et al. 2016). Still, the change of $\mathrm{pH}$ value would also bring about the change in the net surface charge of AAOB and thus hampered chemical forces responsible for adhesion and aggregation of microorganisms (Sandberg and Ahring 1992). Furthermore, the inhibition of extreme $\mathrm{pH}$ was also ascribed to the $\mathrm{pH}$ dependent substrates such as FA and FNA. FA and FNA were hydrophobic and they could diffuse into cytoplasm through cell membrane (Kadam and Boone 1996). $\mathrm{pH}$ could affect the equilibrium of $\mathrm{FA} / \mathrm{NH}_{4}^{+}-$ $\mathrm{N}$ and FNA/ $\mathrm{NO}_{2}^{-}-\mathrm{N}$ (Kadam and Boone 1996; Mosquera-Corral et al. 2005). When the extracellular and intracellular $\mathrm{pH}$ values were different, the concentrations of FA and FNA in both spaces would also differ. Then the concentration gradient would drive the diffusion of FA and FNA across the cell membrane (Jin et al. 2012; Kadam and Boone 1996). That would result in variation of intracellular $\mathrm{pH}$ and create a proton imbalance (Almeida et al. 1995; Sprott and Patel 1986; Wittmann et al. 1995). This made FA and FNA (in cell) transformed into $\mathrm{NH}_{4}^{+}-\mathrm{N}$ and $\mathrm{NO}_{2}^{-}-\mathrm{N}$ constantly, which led to the further increase (alkaline condition) or decrease (acidic condition) of $\mathrm{pH}$ in cell (showed in Fig. 3). Last, extreme pH shock could hamper the utilizability of trace elements (Gadd and Griffiths 1977), which led to the inactivation of AAOB.
Sludge characteristics

The particle size distributions (PSD) of ANAMMOX sludge with $\mathrm{pH}$ shocks were presented in Fig. 4. The extreme $\mathrm{pH}$ could decrease the size of granular sludge (Xing et al. 2015; Li et al. 2015). The diameter of ANAMMOX sludge was $0-5 \mathrm{~mm}$ with the mean diameter of $1.69 \mathrm{~mm}$ at $\mathrm{pH} 7.5$. The percentage of sludge with diameter larger than $2 \mathrm{~mm}$ was 0.444 at pH 6.0 while it was 0.434 at $\mathrm{pH} 7.5$. Besides, at pH 6.0, the mean diameter of sludge was $1.65 \mathrm{~mm}$. Acidic $\mathrm{pH}$ had little effect on sludge size. However, disintegration of ANAMMOX granule was observed when $\mathrm{pH}$ shifted to 9.0. Besides, the frequency of sludge with diameter larger than $2 \mathrm{~mm}$ decreased to 0.254 . The mean diameter of granular sludge was $1.28 \mathrm{~mm}$, which was smaller than that at $\mathrm{pH}$ 7.5. Extremely alkaline $\mathrm{pH}$ could lead to breakage of AAOB, which resulted in decrease of granular diameter. The results found in present work was also agreed with Gao et al. (2010) that the flocs in anaerobic digestion sludge suspension shifted to smaller size at $\mathrm{pH}$ 9.1. Sandberg and Ahring (1992) also detected that extremely alkaline $\mathrm{pH}$ could lead to disintegration of microbial granule, and the percentage of smaller granule rose as $\mathrm{pH}$ increased. The breakage of AAOB in reactor was attributed to the rupture of polysaccharide fibril, which was the support of different cells (Gao et al. 2010; Parker et al. 1972). 

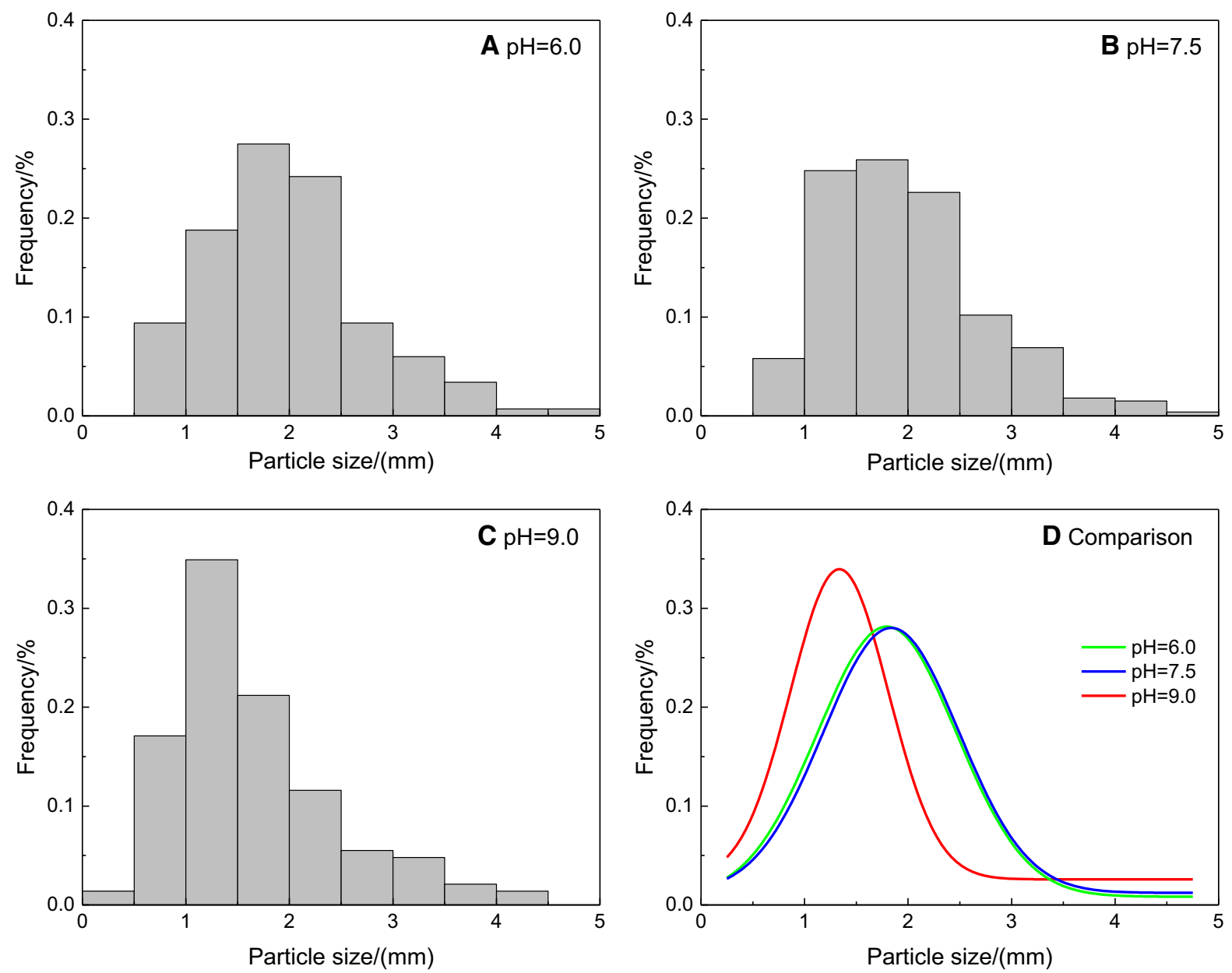

Fig. 4 The PSD of AAOB with pH shock (a pH 6.0; b pH 7.5; c pH 9.0; $\mathbf{d}$ comparison of granular sludge size simulated by Gaussian model)

The small particles formed with alkaline $\mathrm{pH}$ had poor sedimentary property, and the fragment of AAOB was easy to wash out which resulted to decrease of MLSS in reactor. The sludge concentration and settling velocity at different $\mathrm{pH}$ (i.e. $\mathrm{pH} 6.0$, 7.5 and 9.0) were presented in Fig. 5. In general, the sludge concentration and settling velocity were just similar at pH 6 and 7.5. However, sludge concentration at $\mathrm{pH} 9.0$ decreased to $1.39 \mathrm{~g} / \mathrm{L}$. It was lower than that at $\mathrm{pH}$ 7.5. This agreed with Sandberg and Ahring (1992) that the concentrations of TS and VS in UASB reactor decreased when $\mathrm{pH}$ increased.

A higher settling velocity implied a better sludge retention ability, which could stabilize and enhance the performance of ANAMMOX. In this work, the

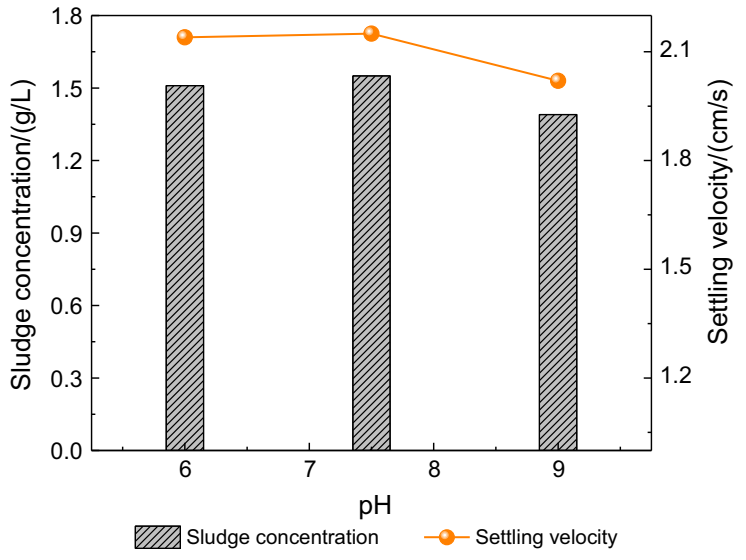

Fig. 5 Sludge concentration and settling velocity at different $\mathrm{pH}$ 
settling velocity was $2.15 \mathrm{~cm} / \mathrm{s}$ at $\mathrm{pH} 7.5$. Tang et al. (2011) obtained a settling velocity of $73-88 \mathrm{~m} / \mathrm{h}$ $(2.03-2.44 \mathrm{~cm} / \mathrm{s})$ in two ANAMMOX reactors, which was similar to present work. However, the settling velocity decreased to $2.02 \mathrm{~cm} / \mathrm{s}$ when $\mathrm{pH}$ was 9.0 . Decreasing size of granular sludge resulted in the decrease of settling velocity. Our results also agreed with $\mathrm{Su}$ et al. (2013). In general, the granular sludge became fragile at $\mathrm{pH} 9.0$ and a slight $\mathrm{pH}$ increase would lead to further damage on ANAMMOX system. This indicated that compared to extremely acidic condition (low $\mathrm{pH}$ ), the extremely alkaline condition (high $\mathrm{pH}$ ) affected ANAMMOX granules much more.

\section{Kinetic analysis}

$\mathrm{pH}$ variations in a typical operation cycle of SBR1 and SBR2 were presented in Figs. S2 and S3. Even though ARR varied with influent $\mathrm{pH}$, there was no linear correlation between them. Besides, ARR was also not correlated with $\Delta \mathrm{pH}$. In alkaline surroundings, FA generation was promoted. ANAMMOX process was nearly completely inhibited at $\mathrm{pH} 9.0$. Kinetic analysis could predict the value which experiment did not easily acquired. Besides, it could provide an effective tool for process control. In present work, five kinetic models were used to simulate the ANAMMOX activity with $\mathrm{pH}$ shock.

\section{The Bell-shaped (A) model}

Figure 6a presented the simulation of $\mathrm{pH}$ shock on ANAMMOX activity using the Bell-shaped (A) model. The correlation coefficient $\left(\mathrm{R}^{2}\right)$ of the plot was 0.9563. Bell-shaped (A) model could well simulate ANAMMOX activity with different $\mathrm{pH}$ values. According to Eq. 2, specific $\mathrm{NH}_{4}^{+}-\mathrm{N}$ removal rate $\left(\mathrm{q}_{\max }\right)$ and optimum $\mathrm{pH}$ value were $0.37 \mathrm{~kg} \mathrm{NH}_{4}^{+}-\mathrm{N} /$ (kg MLSS·d) and 7.47, respectively. In addition, the predicted ' $\omega$ ' value was 1.90 , which indicated that ANAMMOX reaction could occur with $\mathrm{pH}$ of 5.57-9.37.

The Michaelis model

Figure $6 \mathrm{~b}$ depicted the graph plotted between specific $\mathrm{NH}_{4}^{+}-\mathrm{N}$ removal rate $\left(\mathrm{q}_{\max }\right)$ and $\mathrm{pH}$. The values of $\mathrm{q}_{\mathrm{max}}, \mathrm{pK}_{\mathrm{s} 1}$ and $\mathrm{pK}_{\mathrm{s} 2}$ were acquired according to Eq. 3 .
The $\mathrm{q}_{\max }$ was $0.53 \mathrm{~kg} \mathrm{NH}_{4}^{+}-\mathrm{N} /(\mathrm{kgMLSS} \mathrm{d})$. According to the predicated values of $\mathrm{pK}_{\mathrm{s} 1}$ and $\mathrm{pK}_{\mathrm{s} 2}$, ANAMMOX reaction could occur at $\mathrm{pH}$ of 6.80-8.12. This was not in agreement with experimental data. Moreover, the $\mathrm{R}^{2}$ of the plot was only 0.8878 , which suggested that the Michaelis model was not appropriate to predict ANAMMOX activity with $\mathrm{pH}$ shock.

The Ratkowsky model

The Ratkowsky model was applied to predict ANAMMOX activity at various $\mathrm{pH}$ values as shown in Fig. 6c. The values of $\mathrm{pH}_{\min }$ and $\mathrm{pH}_{\max }$ were 5.68 and 9.26, respectively, and $\mathrm{R}^{2}$ was 0.9608 . The simulated values were consistent with experimental data. It suggested applicability of the Ratkowsky model to predict ANAMMOX activity at different $\mathrm{pH}$ values.

The Haldane model

Figure $6 \mathrm{~d}$ described the relationship between specific $\mathrm{NH}_{4}^{+}-\mathrm{N}$ removal rate $\left(\mathrm{q}_{\max }\right)$ and concentration of $\mathrm{H}^{+}$. As a result, the Haldane model failed to predict ANAMMOX activity $\left(\mathrm{R}^{2}=0.7895\right)$. The simulated $\mathrm{q}_{\max }$ was as high as $0.55 \mathrm{~kg} \mathrm{NH}_{4}^{+}-\mathrm{N} /(\mathrm{kgMLSS} \mathrm{d})$, which greatly deviated from experimental data.

The Bell-shaped (B) model

van Hulle et al. (2007) reported that experimental data could well fit the equation of the Bell-shaped (B) model. In this work, the simulated $\mathrm{q}_{\max }$ and $\mathrm{pH}_{\text {opt }}$ were 0.38 and 7.45 , respectively, which were in line with experimental data. However, low $\mathrm{R}^{2}$ (0.8672) indicated poor regression result. As a result, further study was needed to explore if the Bell-shaped (B) model could describe the $\mathrm{pH}$ shock on ANAMMOX process.

Evaluation and validation of kinetic models

The applicable models were evaluated through judging the linear relationship between experimental data and predicted values. In present work, five kinetic models were used to evaluate the $\mathrm{pH}$ on ANAMMOX performance. In order to test the validity of five 

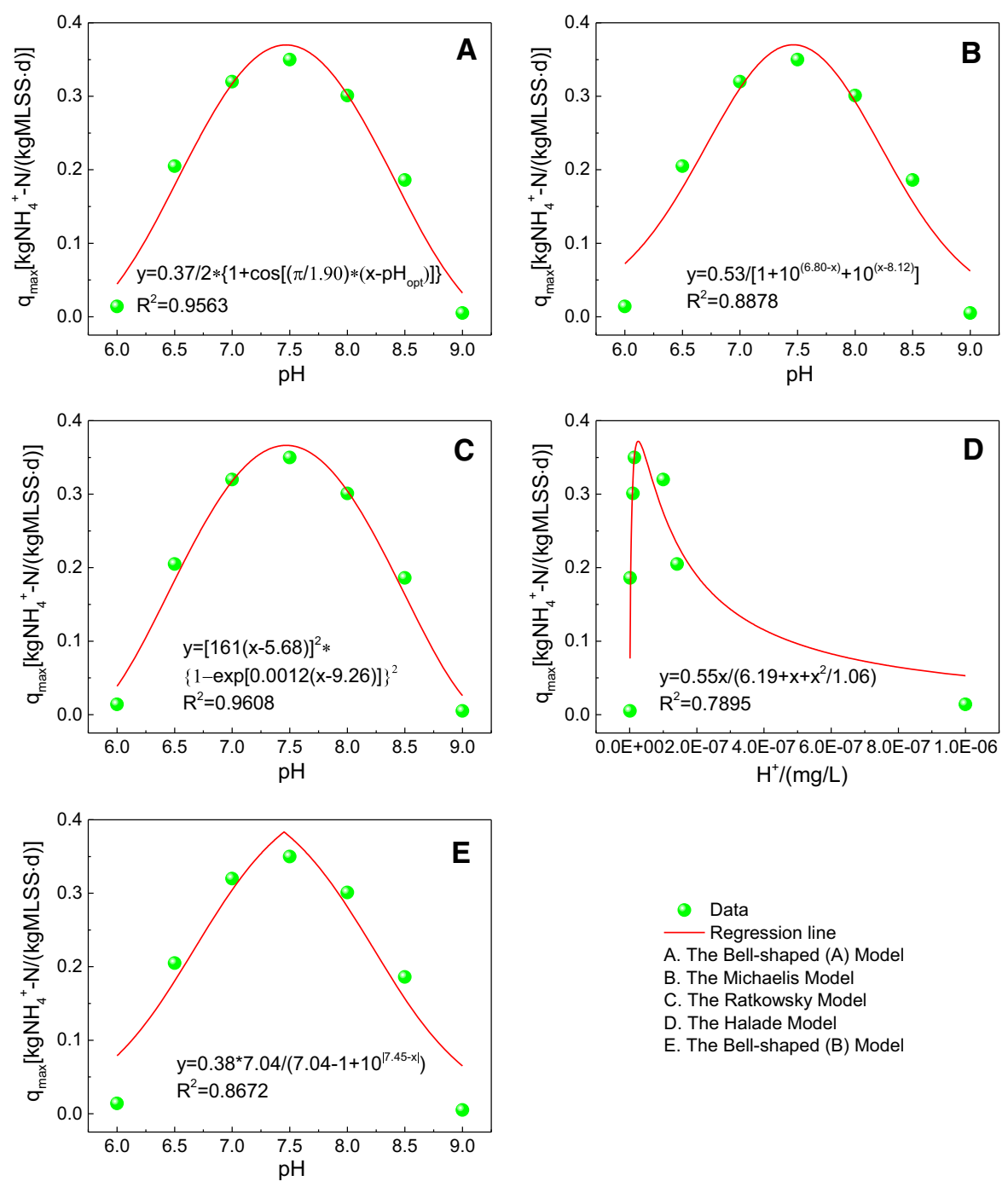

Fig. 6 The regression curve of five kinetic models

models, experimental data were compared with predicted values calculated from models (shown in Fig. 7). Kinetic parameters determined in this work were summarized in Table 2.

Through analyzing these models, the Bell-shaped (A) model and the Ratkowsky model were more applicable to simulate the effect resulting from $\mathrm{pH}$ shock on ANAMMOX activity $\left(\mathrm{R}^{2}>0.95\right)$. Not only $\mathrm{R}^{2}$ of regression line plotted by the Ratkowsky model was higher than that by the Bell-shaped (A) model in Fig. 6, but also the former one was a three-parameter model which was simpler and easier to use than the four-parameter model (the latter one) (Zwietering et al. 1990). Both models could simulate the ANAMMOX activity well with $\mathrm{pH}$ shock. Moreover, both models could predict the $\mathrm{pH}$ range during which ANAMMOX reaction could occur. This was difficult to measure and was important to control nitrogen removal performance. With regard to other three models, though $\mathrm{R}^{2}$ of the plot curve using the Michaelis model was high, the $\mathrm{pH}$ range for ANAMMOX reaction was 6.80-8.12. This deviated from experimental values. In terms of the Haldane model, its application was limited by two factors. Firstly, the independent variable was $\mathrm{H}^{+}$concentration rather than $\mathrm{pH}$ value. $\mathrm{H}^{+}$concentration was more 
Fig. 7 Comparison of experimental data and predicted value
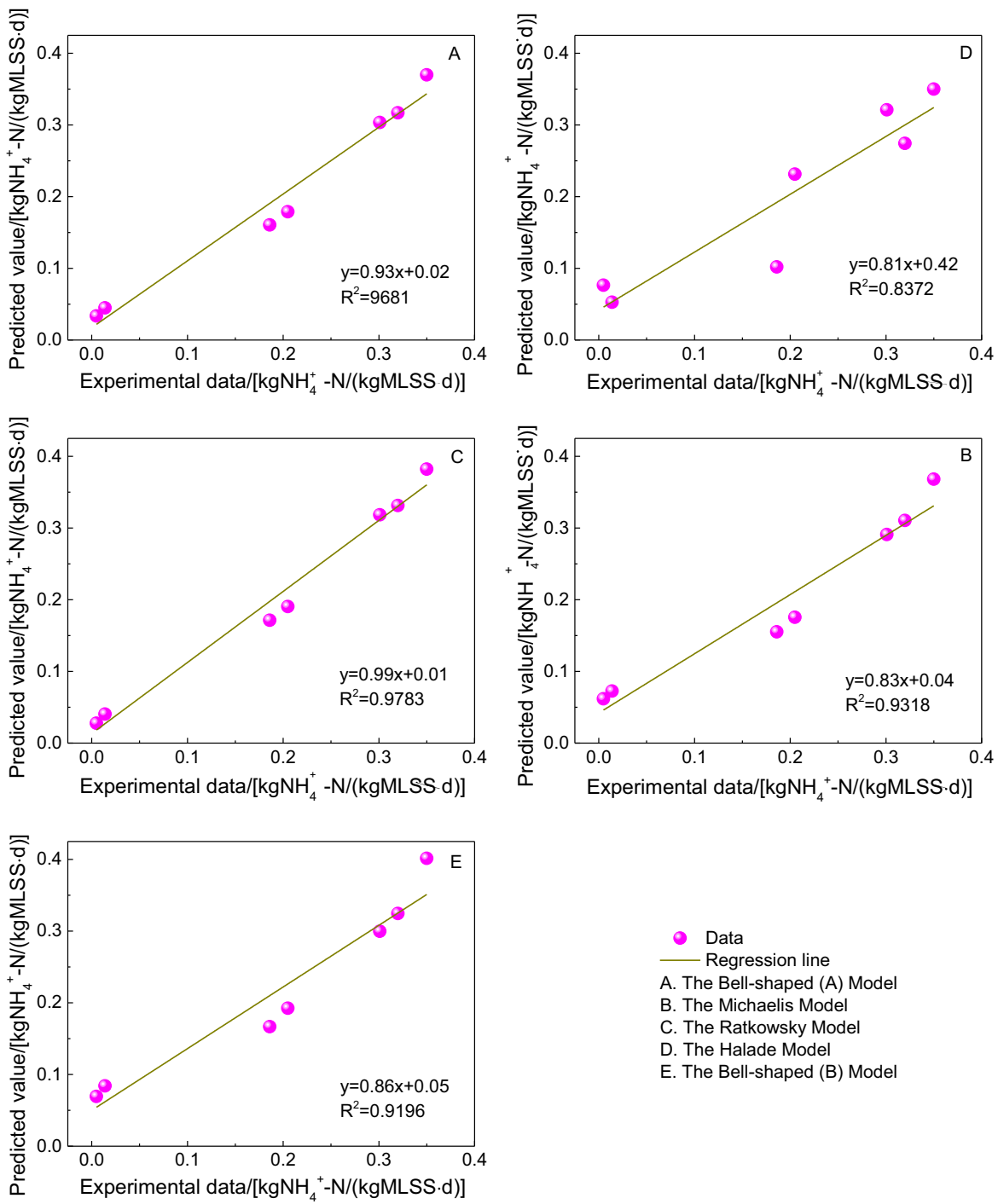

- Data

Regression line

A. The Bell-shaped (A) Model

B. The Michaelis Model

C. The Ratkowsky Model

D. The Halade Model

E. The Bell-shaped (B) Model
Table 2 Summary of kinetic parameter determined in ANAMMOX process

\begin{tabular}{lllllll}
\hline Model & \multicolumn{2}{l}{ Parameter } & & \multirow{2}{*}{$\mathrm{R}^{2}$} \\
\cline { 2 - 6 } & $\mathrm{Q}_{\max }$ & $\mathrm{H}_{\min }$ & $\mathrm{H}_{\max }$ & $\mathrm{H}_{\mathrm{opt}}$ & $\omega$ & \\
\hline Bell-shaped (A) model & 0.37 & - & - & 7.47 & 1.90 & 0.9563 \\
Michaelis model & 0.53 & 6.80 & 8.12 & - & - & 0.8878 \\
Ratkowsky model & - & 5.68 & 9.26 & - & - & 0.9608 \\
Haldane model & 0.55 & - & - & - & - & 0.7895 \\
Bell-shaped (B) model & 0.38 & - & - & 7.45 & - & 0.8672 \\
\end{tabular}

difficult to measure than $\mathrm{pH}$ value. Secondly, the model only predicted the $\mathrm{q}_{\max }$, and the value was not fitted to experimental data precisely. When it came to the Bell-shaped (B) model, though the simulated $\mathrm{q}_{\max }$ and $\mathrm{pH}_{\mathrm{opt}}$ were in agreement with experimental data, the predicated values were not fitted very well to 
experimental data (showed in Fig. 7e). As a result, though the Bell-shaped (B) model was not applicable in this work, it still deserved further study due to well simulation for $\mathrm{q}_{\max }$ and $\mathrm{pH}_{\mathrm{opt}}$.

The Bell-shaped (A) model and the Ratkowsky model indicated that $\mathrm{q}_{\max }$ was $0.37 \mathrm{~kg} \mathrm{NH}_{4}^{+}-\mathrm{N} /$ ( $\operatorname{kgMLSS} \mathrm{d})$ at the optimum $\mathrm{pH}$ value (7.47) in present study. The minimum $\mathrm{pH}$ during which ANAMMOX occurred was 5.68 while the maximum $\mathrm{pH}$ for ANAMMOX reaction was 9.26. Egli et al. (2001) observed that ANAMMOX activity took place only at pH value within 6.5-9. Strous et al. (1999) found that the physiological $\mathrm{pH}$ range of ANAMMOX was 6.7-8.3 in SBR. Both were not consistent with this work. Comprehensive effects resulting from different reactor configurations, operational conditions, as well as wastewater types devoted to the discrepancies.

\section{Conclusions}

Based on nitrogen removal performance with different $\mathrm{pH}$, strongly acidic $(\mathrm{pH} \leq 6.5)$ or alkaline $(\mathrm{pH} \geq 8.5)$ inhibited ANAMMOX process. When influent $\mathrm{pH}$ was below 7.5, effluent $\mathrm{NH}_{4}^{+}-\mathrm{N}$ and $\mathrm{NO}_{2}^{-}-\mathrm{N}$ increased with decreasing $\mathrm{pH}$. At $\mathrm{pH}$ 6.0, effluent $\mathrm{NO}_{2}^{-}-\mathrm{N}$ approached $100 \mathrm{mg} / \mathrm{L}$, and the ratios of $\Delta \mathrm{NO}_{2}^{-}-$ $\mathrm{N}: \Delta \mathrm{NH}_{4}^{+}-\mathrm{N}$ and $\Delta \mathrm{NO}_{3}^{-}-\mathrm{N}: \Delta \mathrm{NH}_{4}^{+}-\mathrm{N}$ approached 2.2 and 1.3 , respectively. Both greatly deviated from theoretical values. When influent $\mathrm{pH}$ was above 7.5, effluent $\mathrm{NH}_{4}^{+}-\mathrm{N}$ and $\mathrm{NO}_{2}^{-}-\mathrm{N}$ increased with increasing $\mathrm{pH}$. At $\mathrm{pH}$ 9.0, ARR and NRR decreased $0.011 \pm 0.004$ and $0.035 \pm 0.004 \mathrm{~kg} /\left(\mathrm{m}^{3} \cdot \mathrm{d}\right)$, respectively. Besides, $\Delta \mathrm{NO}_{2}^{-}-\mathrm{N}: \Delta \mathrm{NH}_{4}^{+}-\mathrm{N}$ deviated from theoretical value. Longer recovery time from $\mathrm{pH} 9.0$ than from $\mathrm{pH} 6.0$ indicated that alkaline surroundings inhibited AAOB greater. The sludge settling velocity was $2.15 \mathrm{~cm} / \mathrm{s}$ at $\mathrm{pH} 7.5$. However, it decreased to $2.02 \mathrm{~cm} / \mathrm{s}$ when $\mathrm{pH}$ was 9.0. Acidic $\mathrm{pH}$ had little effect on sludge size, but disintegration of ANAMMOX granule was achieved with $\mathrm{pH}$ of 9.0. The Bell-shaped (A) model and the Ratkowsky model were more applicable to simulate the effect resulting from $\mathrm{pH}$ shock on ANAMMOX activity $\left(\mathrm{R}^{2}>0.95\right)$, and both could describe ANAMMOX activity well with $\mathrm{pH}$ shock. They indicated that $\mathrm{q}_{\max }$ was $0.37 \mathrm{~kg} \mathrm{NH}_{4}^{+}-\mathrm{N} /$ ( $\mathrm{kgMLSS} \mathrm{d}$ ) at the optimum $\mathrm{pH}$ value (7.47) in present study. The minimum $\mathrm{pH}$ during which
ANAMMOX occurred was 5.68 while the maximum $\mathrm{pH}$ for ANAMMOX reaction was 9.26.

Acknowledgements The work was financially supported by Shandong Provincial Natural Science Foundation (BS2015 HZ007), Shandong Province Higher Educational Science and Technology Program (J15LC61) and Qingdao Municipal Applied Fundamental Research Program (13-1-4-203-jch). The authors also would like to thank the editor and anonymous reviewers for their editing and review.

\section{References}

Ahn YH, Hwang IS, Min KS (2004) ANAMMOX and partial denitritation in anaerobic nitrogen removal from piggery waste. Water Sci Technol 49(5-6):145-153

Aktan CK, Yapsakli K, Mertoglu B (2012) Inhibitory effects of the free ammonia on Anammox bacteria. Biodegradation 23(5):751-762

Almeida JS, Júlio SM, Reis MAM, Carrondo MJT (1995) Nitrite inhibition of denitrification by Pseudomonas fluorescens. Biotechnol Bioeng 46(3):194-201

Anthonisen AC, Loehr RC, Prakasam TBS, Srinath EG (1976) Inhibition of nitrification by ammonia and nitrous acid. Water Pollut Control Fed 48(5):835-852

APHA (1998) Standard Methods for the Examination of Water and Wastewater, 20th edn. American Public Health Association, Washington

Carvajal-Arroyo JM, Puyol D, Li G, Sierra-Álvarez R, Field JA (2014) The role of $\mathrm{pH}$ on the resistance of resting- and active anammox bacteria to $\mathrm{NO}_{2}{ }^{-}$inhibition. Biotechnol Bioeng 111(10):1949-1956

Chung J, Bae W (2002) Nitrite reduction by a mixed culture under conditions relevant to shortcut biological nitrogen removal. Biodegradation 13(3):163-170

Chung J, Bae W, Lee YW, Rittmann BE (2007) Shortcut biological nitrogen removal in hybrid biofilm/suspended growth reactors. Process Biochem 42(3):320-328

Daverey A, Chei PC, Dutta K, Lin JG (2015) Statistical analysis to evaluate the effects of temperature and $\mathrm{pH}$ onanammox activity. Int Biodeter Biodegr 102:89-93

Egli K, Fanger U, Alvarez PJJ, Siegrist H, van der Meer JR, Zehnder AJB (2001) Enrichment and characterization of an anammox bacterium from a rotating biological contactor treating ammonium-rich leachate. Arch Microbiol 175(3):198-207

Fabiano B, Perego P (2002) Thermodynamic study and optimization of hydrogen production by Enterobacter aerogenes. Int J Hydrogen Energ 27(2):149-156

Fernandez I, Dosta J, Fajardo C, Campos JL, Mosquera-Corral A, Méndez R (2012) Short- and long-term effects of ammonium and nitrite on the Anammox process. J Environ Manage 95:S170-S174

Fux C, Marchesi V, Brunner I, Siegrist H (2004) Anaerobic ammonium oxidation of ammonium-rich waste streams in fixed-bed reactors. Water Sci Technol 49(11-12):77-82

Gadd GM, Griffiths AJ (1977) Microorganisms and heavy metal toxicity. Microb Ecol 4(4):303-317 
Gao WJJ, Lin HJ, Leung KT, Liao BQ (2010) Influence of elevated $\mathrm{pH}$ shocks on the performance of a submerged anaerobic membrane bioreactor. Process Biochem 45(8):1279-1287

He S, Niu Q, Ma H, Zhang Y, Li YY (2015) The treatment performance and the bacteria preservation of Anammox: a review. Water Air Soil Poll 226(5):1-16

Henze M, Harremoes P, Jansen JLC, Arvin E (1995) Wastewater treatment: biological and chemical processes. Springer-Verlag, Berlin

Jaroszynski LW, Cicek N, Sparling R, Oleszkiewicz JA (2011) Importance of the operating $\mathrm{pH}$ in maintaining the stability of anoxic ammonium oxidation (anammox) activity in moving bed biofilm reactors. Bioresour Technol 102(14): 7051-7056

Jin RC, Yang GF, Yu JJ, Zheng P (2012) The inhibition of the Anammox process: a review. Chem Eng J 197(29):67-79

Jung JY, Kang SH, Chung YC, Ahn DH (2007) Factors affecting the activity of anammox bacteria during start up in the continuous culture reactor. Water Sci Technol 55(1-2): 459-468

Kadam PC, Boone DR (1996) Influence of pH on ammonia accumulation and toxicity in halophilic, methylotrophic methanogens. Appl Environ Microbiol 62(12):4486-4492

Li Y, Huang Z, Ruan W, Ren H, Zhao M (2015) ANAMMOX performance, granulation, and microbial response under COD disturbance. J Chem Technol Biot 90(1):139-148

Lu HF, Ji QX, Ding S, Zheng P (2013) The morphological and settling properties of ANAMMOX granular sludge in highrate reactors. Bioresour Technol 143:592-597

Mosquera-Corral A, Gonzalez F, Campos JL, Méndez R (2005) Partial nitrification in a SHARON reactor in the presence of salt and organic carbon compounds. Process Biochem 40(9):3109-3118

Mu Y, Ren TT, Yu HQ (2008) Drag coefficient of porous and permeable microbial granules. Environ Sci Technol 42(5):1718-1723

Okamoto H, Kawamura K, Nishiyama T, Fujii T, Furukawa K (2012) Development of a fixed-bed anammox reactor with high treatment potential. Biodegradation 24(1):99-110

Park S, Bae W, Chung J, Baek SC (2007) Empirical model of the $\mathrm{pH}$ dependence of the maximum specific nitrification rate. Process Biochem 42(12):1671-1676

Parker DS, Kaufman WJ, Jenkins D (1972) Floc Breakup in Turbulent Flocculation Processes. J Sanit Eng Division 98(1):79-99

Puyol D, Carvajal-Arroyo JM, Li GB, Dougless A, FuentesVelasco M, Sierra-Alvarez R, Field JA (2014a) High pH (and not free ammonia) is responsible for Anammox inhibition in mildly alkaline solutions with excess of ammonium. Biotechnol Lett 36(10):1981-1986

Puyol D, Carvajal-Arroyo JM, Sierra-Alvarez R, Field JA (2014b) Nitrite (not free nitrous acid) is the main inhibitor of the anammox process at common $\mathrm{pH}$ conditions. Biotechnol Lett 36(3):547-551

Qiao S, Kawakubo Y, Cheng Y, Nishiyama T, Fujii T, Furukawa $\mathrm{K}$ (2009) Identification of bacteria coexisting with anammox bacteria in an upflow column type reactor. Biodegradation 20(1):117-124

Qiao S, Yin X, Zhou J, Furukawa K (2014) Inhibition and recovery of continuous electric field application on the activity of anammox biomass. Biodegradation 25(4):505513

Sandberg M, Ahring BK (1992) Anaerobic treatment of fish meal process waste-water in a UASB reactor at high $\mathrm{pH}$. Appl Microbiol Biotechnol 36(6):800-804

Segel IH (1975) Enzyme kinetics: behavior analysis of rapid equilibrium and steady-state enzyme systems. Wiley Classics Library 32:1503-1515

Sprott GD, Patel GB (1986) Ammonia toxicity in pure cultures of methanogenic bacteria. Syst Appl Microbiol 7(2-3):358-363

Strous M, Van Gerven E, Zheng P, Kuenen JG, Jetten MSM (1997) Ammonium removal from concentrated waste streams with the anaerobic ammonium oxidation (Anammox) process in different reactor configurations. Water Res 31(8):1955-1962

Strous M, Heijnen JJ, Kuenen JG, Jetten MSM (1998) The sequencing batch reactor as a powerful tool for the study of slowly growing anaerobic ammonium-oxidizing microorganisms. Appl Microbiol Biotechnol 50(5): 589-596

Strous M, Kuenen JG, Jetten MSM (1999) Key physiology of anaerobic ammonium oxidation. Appl Environ Microb 65(7):3248-3250

Su KZ, Ni BJ, Yu HQ (2013) Modeling and optimization of granulation process of activated sludge in sequencing batch reactors. Biotechnol Bioeng 110(5):1312-1322

Tang CJ, Zheng P, Mahmood Q, Chen JW (2009) Start-up and inhibition analysis of the Anammox process seeded with anaerobic granular sludge. $J$ Ind Microbiol Biot 36(8):1093-1100

Tang CJ, Zheng P, Wang CH, Mahmood Q, Zhang JQ, Chen XG, Zhang L, Chen JW (2011) Performance of high-loaded ANAMMOX UASB reactors containing granular sludge. Water Res 45(1):135-144

Van de Graaf AA, de Bruijn P, Robertson LA, Jetten MSM, Kuenen JG (1996) Autotrophic growth of anaerobic ammonium-oxidizing micro-organisms in a fluidized bed reactor. Microbiology 142(8):2187-2196

van der Star WRL, Abma WR, Blommers D, Mulder JW, Tokutomi T, Strous M, Picioreanu C, van Loosdrecht MCM (2007) Startup of reactors for anoxic ammonium oxidation: experiences from the first full-scale anammox reactor in Rotterdam. Water Res 41(18): 4149-4163

Van Hulle SWH, Volcke EIP, Teruel JL, Donckels B, van Loosdrecht MCM, Vanrolleghem PA (2007) Influence of temperature and $\mathrm{pH}$ on the kinetics of the Sharon nitritation process. J Chem Technol Biot 82(5):471-480

Waki M, Tokutomi T, Yokoyama H, Tanaka Y (2007) Nitrogen removal from animal waste treatment water by anammox enrichment. Bioresour Technol 98(14):2775-2780

Wang J, Wan W (2009) Kinetic models for fermentative hydrogen production: a review. Int $\mathrm{J}$ Hydrogen Energ 34(8):3313-3323

Wittmann C, Zeng AP, Deckwer WD (1995) Growth inhibition by ammonia and use of a $\mathrm{pH}$-controlled feeding strategy for the effective cultivation of Mycobacterium chlorophenolicum. Appl Microbiol Biotechnol 44(3):519-525

Xing BS, Guo Q, Yang GF, Zhang ZZ, Li P, Guo LX, Jin RC (2015) The properties of anaerobic ammonium oxidation 
(anammox) granules: roles of ambient temperature, salinity and calcium concentration. Sep Purif Technol 147:311-318

Yin Z, dos Santos CED, Vilaplana JG, Sobotka D, Czerwionka K, Damianovic MHRZ, Xie L, Morales FJF, Makinia J (2016) Importance of the combined effects of dissolved oxygen and $\mathrm{pH}$ on optimization of nitrogen removal in anammox-enriched granular sludge. Process Biochem 51(9):1274-1282

Zwietering MH, Jongenburger I, Rombouts FM, van 't Riet K (1990) Modeling of the bacterial growth curve. Appl Environ Microb 56(6):1875-1881 